\title{
The Effect of Personality Traits on Organizational Commitment: Moderating Role of Distributive Justice: A Case of Public Sector Female Colleges of District Peshawar
}

\author{
IMRAN SAEED \\ International Islamic University, Islamabad \\ GHAYYUR QADIR \\ Lecturer, Institute of Business Studies and Leadership \\ Abdul Wali Khan University, Mardan \\ ghayyurqadir@awkum.edu.pk \\ SAIF ULLAH KHAN \\ Lecturer, Institute of Management Studies, Peshawar
}

\begin{abstract}
Many studies have been conducted on personality traits in different organizations and an in different culture, different region and in different countries. The current study is talk about the two traits of personality i.e agreeableness and neuroticism and their effect on employee organizational commitment. And the main contribution of this study is to introduce distributive justice as a moderator variable. Data was collected from public sector female colleges of a Peshawar district. The sample size of this study was $(n=120)$ and the data was cross-sectional in nature. The results reveal that the direct effect of agreeableness and distributive justice on organizational commitment is significant and positive while neuroticism has insignificant effect on organizational commitment. While the combined effect shows that both interactions terms has positive and significant effect on organizational commitment.
\end{abstract}

Key Words: Agreeableness, Neuroticism, Organizational Commitment and Distributive Justice

\section{Introduction}

This study is specifically carried out for investigating the effect of Agreeableness and Neuroticism on Organizational commitment in the MS students of Agriculture University Peshawar. In the present situation it is very important for each and every organization to work on the internal psyche of employees, shareholders and stake holders in order to make them committed to the organization because if it is not so then the employees cannot work selflessly for the organization rather they would only go for personal achievements and not for organizational achievements. Therefore in order to save organization from this chaos and anarchy; organization must practice the tool of distributive justice which will ultimately lead towards organizational commitment. In organizational commitment the personality of an individual involved, plays a vital role. 
Personality is referred to the set of characteristics of cognitive nature of a person which effects the direction of his thinking. In other words we can also define personality as those mental characteristics which differentiate one person from another in accordance with his position (Plomin et al, 1998). Lewis Goldberg proposed Big Five model in regards with the characteristics of personality which is known as Five-Dimension personality model.

1. Openness to Experience: The internal drive of an individual towards being imaginative, independent and variety lover rather than being static.

2. Conscientiousness: The internal drive of an individual towards being organized and disciplined rather than being careless.

3. Extraversion: A social able and interactive personality is an extravert personality who denies being somber and reserved.

4. Agreeableness: A person can be called Agreeable who trusts others and is soft hearted by nature.

5. Neuroticism: It is the tendency of an individual in order to be self-satisfied and calm vs. the owner of insecure and paranoid personality (Santrok, 2008).

Distributive Justice which is the second main item of research that targets the distribution of goods and resources which are considered important in regards with the social criteria (Foa \& Foa, 1974) and the fairness that is received by an individual in the outcome they receive (Frohlich, 2007). If we have a look so we will find that there are number of rules used to allocate these resources and goods of social nature (Deutsch, 1985) but 2 are the most attention grasping in them: the rule of equity according to which people must be given rewards in accordance with the input provided by them in the shape of their contribution. (Adams, 1963, 1965) and the second rule is equality rule according to which all members of the group are rewarded on same basis without considering their input as important. Therefore it is quite evident that by practicing the justice in the distribution of organizational rewards can ultimately result in the phenomenon called organizational commitment.

Organizational commitment is that dimension of an individual which is very necessary to be made available at work place because due to this a partnership sense can be created between the worker and work place. Organizational commitment is therefore the equalization degree that is necessary to be achieved by the organization in order to make its employees motivated to not only accept the rules and objectives of the organization but also to make them a loyal part of overall organizational effort (Mowdy et al, 1982). Therefore from the above discussion we can say that in order to bring stability in organization on every level, organization must make its employees committed towards it.

\subsection{Research Objective}

The objectives of this research are as under:

- To investigate the effect of Neuroticism and Agreeableness in regards with Organizational Commitment.

- To investigate the mediating role of Distributive justice between Neuroticism, Agreeableness and Organizational Commitment. 


\section{Literature Review}

\subsection{Organizational Commitment}

Different researchers have different views about commitment concept with organization. Organizational commitment links itself to loyalty of an employee towards their workplace, their sense of identification to their organization (i.e., the level of pride they get at workplace and to internalize the goals of their organization), and their ultimate attachments with organizational workups (i.e. personal hardships faced just for the improvement of organization) (Mowday, Porter, \& Steers, 1982). However, in accordance with the views of different scholars; it is just the loyalty of employees towards the place they are involved in which defines their commitment level (Price \& Mueller, 1986). If we talk about the researchers of Taiwan so we will see that most of them show alignment with the concept presented by Porter, Steer, Mowday, \&Boulian (1974); that concept elaborates commitment to the workplace as the extent to which an employee feels recognized and participative in regards with the place where they invest their professional abilities. Therefore to explain this relationship of employees and his workplace is hard. Organizational commitment is one's psychological commitment with organization.

It is indeed worth considering analyzing the commitment of employee towards his job field which is basically dependent on the relationship of worker and their work place and how this bonding of employee and his work place leads to the inducement of positive behavior in workers. (e.g., behavior of worker as firm's citizen etc) (See Meyer \& Allen, 1997).There is three characteristics that an organizational commitment has, (a) value commitment, (b) effort commitment, (c) retention commitment. Organizational commitment is an individual willingness to utilize his or her efforts and have retention intentions in an organization. However the vast horizon of literature also explains those factors which decrease the commitment level towards job place such as conflicts and ambiguities in the roles performed by employees along with the problems faced by employee from their family side (Griffin, 2006; Hogan, Lambert, Jenkins, \&Wambold, 2006; Lambert, Hogan, Paoline, \& Clarke, 2005).

\subsection{Distributive Justice}

Distributive justice concerns the nature of a socially just allocation of goods in a society. A society in which incidental inequalities in outcome do not arise would be considered a society guided by the principles of distributive justice. The concept includes the available quantities of goods, the process by which goods are to be distributed, and the resulting allocation of the goods to the members of the society. Often contrasted with just process, which is concerned with the administration of law, distributive justice concentrates on outcomes. This subject has been given considerable attention in philosophy and the social sciences. In Social Psychology, Distributive Justice is defined as perceived fairness of how rewards and costs are shared by (distributed across) group member (Forsyth, 2006).For example, when workers of the same job are paid different salaries, group members may feel that distributive justice has not occurred. To determine whether distributive justice has taken place, individuals often turn to the distributive norms of their group (Forsyth, 2006).A norm is the standard of behavior that is required, desired, or designated as normal within a particular group (Farlex, 2013). If rewards and 
costs are allocated according to the designated distributive norms of the group, distributive justice has occurred (Deutsch, 1975).

\subsubsection{Types of Distributive Norms}

1. Equity: Member's outcomes should be based upon their inputs. Therefore, an individual who has invested a large amount of input (e.g. time, money, and energy) should receive more from the group than someone who has contributed very little. Members of large groups prefer to base allocations of rewards and costs on equity.

2. Equality: Regardless of their inputs, all group members should be given an equal share of the rewards/costs. Equality supports that someone who contributes $20 \%$ of the group's resources should receive as much as someone who contributes $60 \%$.

3. Power: Those with more authority, status, or control over the group should receive more than those in lower level positions.

4. Need: Those in greatest needs should be provided with resources needed to meet those needs. These individuals should be given more resources than those who already possess them, regardless of their input.

5. Responsibility: Group members who have the most should share their resources with those who have less.

\subsection{Distributive Justice in Organizations}

In the context of organizational justice, distributive justice is conceptualized as fairness associated with outcomes decisions and distribution of resources. The outcomes or resources distributed may be tangible (e.g., pay) as well as intangible (e.g., praise). Distributive justice targets the practice of fairness while allotting the rewards which are considered worthy in regards with social means (Foa \& Foa, 1974) and the perceived fairness of the outcomes that one receives (Frohlich, 2007). It is the perceived fairness of the rewards distribution. The concept of ensuring justice in distribution is basically originated from a theory that is named as Social Exchange Theory (Blau, 1964; Adams, 1965), which is having its all focuses focused on the equity while defining the exchanges of subsequent nature. Equity and equality theory also represent the beliefs of fair reward distribution. The rule exercised by this distribution tactic called equity is to reward an individual in regards with his efficient provision to the organization (Adams, 1963; 1965), and on other side; in the other tactic of distribution called equality; the individual must be rewarded equally without taking the level of his input into consideration. (Deutsch, 1975). Distribution justice also refers to how an individual and societies distribute the benefits and burdens in fair manners. Because our society has a limited resources and wealth, now the question is arises, how to distribute them? And the most common answer is that the public wealth should be distributed in reasonable manner that each and every individual get the fair distribution and fair share.

\subsection{Research Hypotheses}

$\boldsymbol{H}_{0}$ : There is insignificant relationship between Agreeableness and Organizational Commitment.

$\boldsymbol{H}_{1}$ : There is significant relationship between Agreeableness and Organizational Commitment. 
$\boldsymbol{H}_{0}$ : There is insignificant relationship between Neuroticism and Organizational Commitment.

$\boldsymbol{H}_{2}$ : There is significant relationship between Neuroticism and Organizational Commitment.

$\boldsymbol{H}_{0}$ : There is insignificant relationship between Distributive Justice and Organizational Commitment.

$\boldsymbol{H}_{3}:$ There is significant relationship between Distributive Justice and Organizational Commitment.

$\boldsymbol{H}_{0}:$ Distributive justice will insignificantly moderate the relationship between agreeableness and organizational commitment.

$\boldsymbol{H}_{4}:$ Distributive justice will significantly moderate the relationship between agreeableness and organizational commitment.

$\boldsymbol{H}_{0}:$ Distributive justice will insignificantly moderate the relationship between neuroticism and organizational commitment.

$\boldsymbol{H}_{5}:$ Distributive justice will significantly moderate the relationship between neuroticism and organizational commitment.

\section{Methodology}

Ojo (2003) defined the term methodology as a set of rules and procedures of explicit nature on which we base a research in regards with the claims of knowledge which are evaluated. This section encompasses the methods which are utilized for the achievement of defined objectives of the study under consideration. This chapter covers the population of the research study, sampling method/procedure, and sample size, theoretical framework, research hypothesis, variables of the research, their measurements, data collection and data analysis. All these are illustrated in the subsequent sections.

\subsection{Sampling and Sample size}

In the research study considered, female public sector colleges of a district Peshawar was taken as a universe of the study. Convenient sampling technique was used in this study. And the total sample size of this study was $(n=120)$, from academic as well as administration staff.

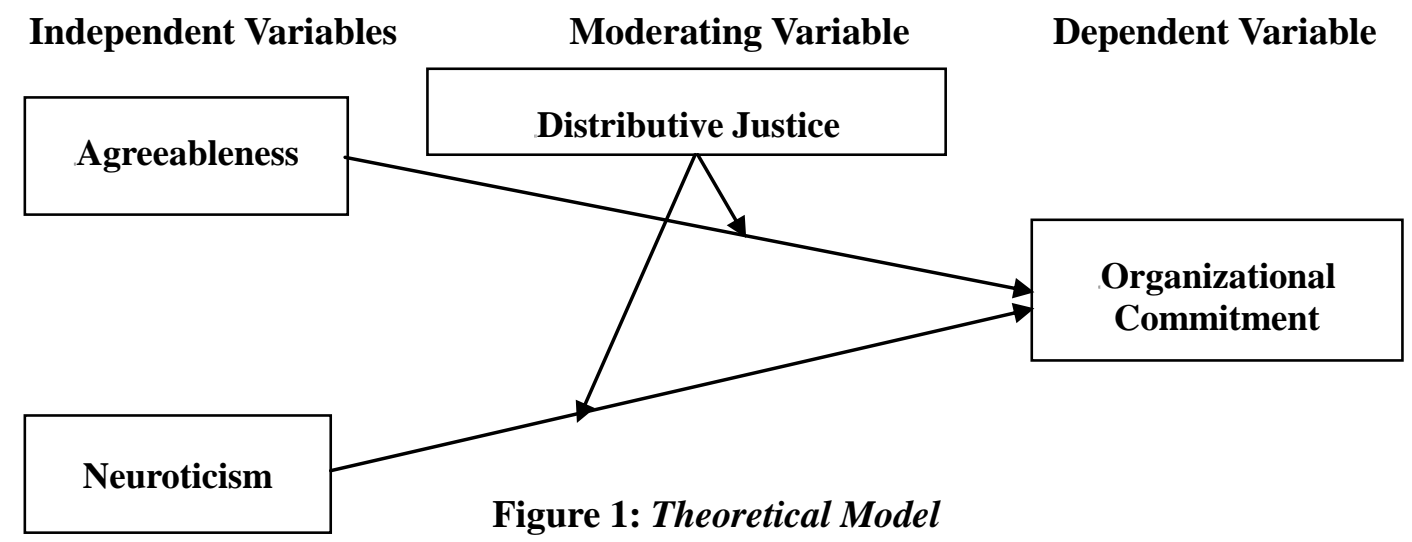




\subsection{Data Collection}

Data collection comprises itself as a pivotal component of a research. This study utilized primary data that was gathered through four different questionnaires which was consolidated into one. The entire questionnaire distribution was random among the different employees of public sector colleges of a Peshawar district. For preserving this research from any erroneous effect the questionnaire was personally administered.

\subsection{Data Analysis}

In order to infer about the collected data we have utilized the Statistical Package for Social Sciences (SPSS) v. 20. Since the study used qualitative variables, so the results were shown in terms of counts and percentages. To develop the relationship among the variables: agreeableness, neuroticism, distributive justice and organizational commitment correlation and regression analysis were utilized. Regression analysis is expressed in equation as:

$\mathrm{Y}=\mathrm{a}+\mathrm{bx}$

\section{Results and Discussion}

\subsection{Distribution of Respondents Regarding Demographic Variables}

The data for this research study was collected from the different employees of public sector colleges of a Peshawar district with the total figure of respondents 120 as sample. The classification of the Demographic variables: age, income per month, specialization and gender is explained in counts and percentages and is presented in the tables 4.1 and 4.2 below. The table 3highlights the distribution of respondents in accordance with their age, experience and specialization while table 4 explains the distribution of the respondents in regards with their gender. In accordance with the age group distribution, most of the respondents were counted in the age group of 26 to 30 with the highest percentage of $76.8 \%, 12$ respondents came under the age line of 31 to 35 with the percentage of $9.6 \%$; while the percentages of $8.8 \%, 3.2 \%$ and $1.6 \%$ were recorded for the age groups of 36 to 40,20 to 25 and 41 and above. The second demographic variable under study was income in which the maximum percentage was followed by the income group of 10,000-20,000 with the percentage figure of $27.2 \%$ while for other income groups: 41,000-50,000, 51,000 and above, 21,000-30,000 and $31,000-40,000$ the recorded percentages were $24 \%, 18 \%, 16 \%$ and $14.4 \%$ respectively. The last demographic variable in this table described specialization fields of the respondents in which maximum respondents were from the Admin side with the highest percentage of $46.7 \%$; respondents from the group of Junior Teacher carried the percentage of $38.3 \%$ while respondents of the Senior Teacher recorded the percentage figure of $14.2 \%$. 
Table 4.1: Sample Description

\begin{tabular}{|c|c|c|c|c|c|c|c|c|}
\hline \multirow{2}{*}{$\begin{array}{l}\text { Age } \\
\text { Age } \\
\text { Group } \\
\text { (Years) }\end{array}$} & \multirow[b]{2}{*}{ No } & \multirow[b]{2}{*}{$(\%)$} & \multicolumn{2}{|l|}{ Income per month } & \multicolumn{2}{|r|}{ Specialization } & \multirow[b]{2}{*}{ No } & \multirow[b]{2}{*}{$(\%)$} \\
\hline & & & $\begin{array}{l}\text { Income Group } \\
\text { (Rs) }\end{array}$ & No & $(\%)$ & Job title & & \\
\hline $20-25$ & 4 & $(3.2)$ & $10,000-20,000$ & 34 & $(27.2)$ & Admin & 46 & (38.3) \\
\hline $26-30$ & 96 & (76.8) & $21,000-30,000$ & 20 & (16) & Junior Teacher & 56 & (46.7) \\
\hline $31-35$ & 12 & (9.6) & $31,000-40,000$ & 18 & (14.4) & Senior Teacher & 17 & $(14.2)$ \\
\hline $36-40$ & 11 & $(8.8)$ & $41,000-50,000$ & 30 & (24) & Assistant Professor & 1 & (.8) \\
\hline $\begin{array}{l}41 \text { and } \\
\text { above }\end{array}$ & 2 & (1.6) & $\begin{array}{l}51,000 \quad \text { and } \\
\text { above }\end{array}$ & 23 & $(18$ & $\begin{array}{l}\text { Associate } \\
\text { Professor } \\
\text { and Professor }\end{array}$ & 0 & (0) \\
\hline Total & 100 & & Total & 100 & & Total & & \\
\hline
\end{tabular}

\subsection{Reliability Analysis}

The Cronbach's alpha of variables which included in this study are here given in table no 4.2. The alpha values of all variable shows that the data which collected for this study are reliable, the alpha value of Agreeableness is $\alpha=.77$, Neuroticism $\alpha=.71$, Distributive justice $\alpha=.68$ and Organizational commitment $\alpha=68$.

Table 4.2: Cronbach's alpha

\begin{tabular}{|lll|}
\hline Variable & Cronbach's alpha & Remarks \\
\hline Agreeableness & 0.770 & Reliable \\
Neuroticism & 0.716 & Reliable \\
Distributive justice & 0.687 & Reliable \\
Organizational & 0.684 & Reliable \\
commitment & & \\
\hline
\end{tabular}

\subsection{Regression Analysis}

The statistical tool of Regression analysis was utilized in order to see the significant or insignificant effect of agreeableness, neuroticism and distributive justice on organizational commitment. It is therefore worthy to mention that since the data was cross sectional and qualitative in nature; the determined value of coefficient was expected to be low that is why the primarily reliance was based on $t$ ratio, $p$ value and $f$ value.

\subsection{Regression Analysis between Agreeableness and Organizational Commitment}

Table 4.3 shows that there is significant and positive relationship between agreeableness and organizational commitment i.e $\mathrm{R}$ square $=.473, \beta=.294$, and $\mathrm{p}=.002$, so the overall relationship and effect of agreeableness on organizational commitment is significant, these results are aligned with (Meyer \& Allen, 1997). The other trait i.e neuroticism has negative and insignificant relationship with organizational commitment, the value indicate that Rsquare $=.003, \beta=.064$, and $p=.563$, this relationship results are aligned with Carducci, Bernardo J (2009). The moderator variables which is distributive justice has also positive and significant effect on organizational commitment, here the values shows that $\mathrm{R}$ square $=.343, \beta=.128$, and $\mathrm{p}=.04$, so these results are matching with the prior research of Costa. PT \& McCrae, RR (1987). Here in this study there are two 
independent variables so here we have create two interaction terms, the first interaction term i.e distributive justice*agreeableness, the results find that there is positive and significant effect of moderator variable on organizational commitment, the results shows that $\mathrm{R}$ square $=.275, \beta=.163$, and $p=.05$. so it shows that moderator variables has positive and significant effect on organizational commitment which aligned with prior research of DeNeve KM, Cooper C (1998), they find that there is positive effect of distributive justice on organizational commitment. Here in this study DJ is used as a moderator variable. The second interaction term i.e distributive justice*neuroticism, as direct relationship of neuroticism and organizational commitment is insignificant, so here the combined effect of distributive justice and neuroticism show positive and significant relationship, the value of a regression analysis shows that $\mathrm{R}$ square $=.24, \beta=.246$ and $\mathrm{p}=.006$.

Table 4.3: Regression and moderation analysis

\begin{tabular}{|llllll|}
\hline Variables & Model 1 & Model 2 & Model 3 & Model 4 & Model 5 \\
\hline Agreeableness & $.294^{* *}$ & & & & \\
$\begin{array}{l}\text { Neuroticism } \\
\text { Distributive Justice }\end{array}$ & & .064 & & & \\
$\begin{array}{l}\text { Justice * Agreeableness } \\
\text { Distributive Justice * }\end{array}$ & & & $.128^{*}$ & & \\
$\begin{array}{l}\text { Neuroticism } \\
\text { R Squared }\end{array}$ & & & & $.163^{*}$ & \\
\hline
\end{tabular}

Note: $* \mathrm{p}<.05, * * \mathrm{p}<.01$.

\section{Discussion and Conclusion}

It is illustrated the summary and conclusion inferred on the basis of the findings obtained from the analysis of agreeableness, neuroticism, distributive justice and organizational commitment of the public sector colleges of Peshawar districts. This research study was carried out in order to elaborate the effect of agreeableness and neuroticism on organizational commitment with the moderating role of distributive justice among the female staff working in public sector colleges of district Peshawar. In order to achieve the objectives of this research study, primary data was gathered from a sample of 120 respondents. This sample was taken by utilizing the method of convenient sampling. A structured closed ended questionnaire was utilized to gather the required information from the respondents. These questionnaires were randomly distributed among the female staff working in public sector colleges of district Peshawar $(\mathrm{n}=120)$. The perception of the respondents was measured by utilizing five point Likert scale. Cronbach's alpha was used for the affirming the reliability of the collected data.

The statistical tool of Pearson Correlation was grounded to obtain comparisons of means regarding the Demographic variables, Agreeableness, Neuroticism, Distributive justice and Organizational commitment with the confidence interval of $(\mathrm{P}<0.01)$. The results inferred positive significant relationship among all the variables understudy except neuroticism which shows insignificant relation with organizational commitment. This figure in actual clarifies that: if an employee is agreeable by nature so he will not rebel any of the rules of organization and thus will show higher organizational commitment. 
In order to give further clarification in regards with research objectives, regression analysis was also utilized for the variables of the study. It is worthy to mention that since the data was cross sectional and qualitative in nature; the determined value of coefficient was expected to be low that is why the primarily reliance was based on t ratio, $\mathrm{p}$ value and $\mathrm{f}$ value. The results obtained from regression analysis of agreeableness and Organizational commitment $(\mathrm{B}=0.293$, $\mathrm{t}$-ratio $=3.201$, $\mathrm{p}$-value $=0.002$, $\mathrm{F}$ value $=10.284$, and $\mathrm{R}$ square $=0.473$ ). The results also inferred positive but insignificant association between neuroticism and organizational commitment $(\mathrm{B}=0.064$, $\mathrm{t}$-ratio $=0.579$, $\mathrm{p}$-value $=0.563, \mathrm{~F}$ value $=0.336$, and $\mathrm{R}$ square $=0.003$ ). Moreover, the results regarding distributive justice and organizational commitment were counted as significant $(B=0.128$, t-ratio $=2.554, \mathrm{p}$-value $=0.04, \mathrm{R}$ square $=0.343$ ). the main contribution in this study as to introduce the moderating role of distributive justice so the results shows that distributive has significant and positive relationship with organizational commitment, the values of both interaction term are $\mathrm{R}$ square $=.275, \beta=.163, \mathrm{t}=4.01$ and $\mathrm{p}=.05$ and $\mathrm{R}$ square $=.24$, $\beta=.246, t=2.74$ and $p=.006$. It was thus found out in this study of female staff working in public sector colleges of district Peshawar that agreeableness and distributive justice play a vital role in making an individual committed while neuroticism is that personality factor which demolishes the spirit of commitment in an individual towards the organization.

\subsection{Conclusion}

This research studied the effect of agreeableness and neuroticism on organizational commitment with the moderating role of distributive justice among the female staff working in public sector colleges of district Peshawar. The conceptual research framework of this study showed a considerate association among variables which were taken into account for conducting the study. From this research study, it was finalized that there is a positive and relations between agreeableness and organizational commitment while a negative association is observed among the neuroticism and distributive justice with organizational commitment among the female staff working in public sector colleges of district Peshawar. The generalization of data showed that the female staff working in public sector colleges of district Peshawar possessed positive perception regarding the distributions.

The following recommendations are recommended for the data under study:

1. Agreeableness is that personality factor which by every mean sustain employee as committed to the organization. Therefore, organization must highlight those who are agreeable by nature because they can bear any kind of bad rather worst situation and can prove their loyalty selflessly

2. Every university must give a keen concentration towards their distributions of rewards to which in case of students are: management rules and regulations, management collaboration with students etc, in order to make them committed to the organization. Otherwise, the contrast of it will make them hostile and rebellion to all rules and regulations of the university.

3. If the universities do not assure fairness in all of their defined distributions so it will make their student neurotic which will ultimately have negative effects on the commitment level and will not result in making them an effective stake of the organization. The universities should emphasize on individualistic approach in 
regards with students by ensuring fairness in every operation that is conducted in the university. This will enhance the commitment level of the students towards the organization and they will not only become agreeable but will also result in "positive word of mouth marketing" from their side which ultimately will result in increasing the goodwill of university in general society.

\section{References}

Adams, J. S. (1963). Toward an understanding of inequity. Journal of Abnormal and Social Psychology, 67, 422-436.

Adams, J. S. (1965). Inequity in social exchange. In L. Berkowitz (Ed.), Advances in experimental social psychology, vol. 2, 267-299, New York: Academic Press.

Budaev S.V. (1999). Sex differences in the big five personality factors: Testing an evolutionary hypothesis, Personality and Individual Differences, 26, 801-813.

Caldwell, D. F. and Burger, J.M. (1998). Personality characteristics of job applicants and success in screening interviews, Personnel Psychology, 51, 119-136.

Carducci, B. J. (2009). The psychology of personality: Viewpoints, research, and applications. John Wiley \& Sons.

Costa, P. T., \& McCrae, R. R. (1987). Neuroticism, somatic complaints, and disease: is the bark worse than the bite?.Journal of personality, 55(2), 299-316.

DeNeve, K. M., \& Cooper, H. (1998). The happy personality: a meta-analysis of 137 personality traits and subjective well-being. Psychological bulletin, 124(2), 197.

Deutsch, M. (1975). Equity, equality, and need: What determines which value will be used as the basis of distributive justice?.Journal of Social Issues, 31(3), 137-149.

Digman, J. M. (1990). Personality structure: Emergence of the five-factor model. Annual review of psychology, 41(1), 417-440.

Dolan, S. L. (2006). Stress, self-esteem, health and work. Palgrave Macmillan.

Farlex. (2013). Norm. Farlex clipart collection. Retrieved March 13, 2013 from http://www.thefreedictionary.com/norm.

Fatt, C. K., Khin, E. W. S., \&Heng, T. N. (2010). The impact of organizational justice on employee's job satisfaction: The Malaysian companies perspectives. American Journal of Economics and Business Administration, 2(1), 56.

Fiske, S. T., Gilbert, D. T., \&Lindzey, G. (2009). Handbook of Social Psychology, Hoboken, NJ: Wiley.

Forsyth, D. R.(2006). Conflict. In Forsyth, D. R., Group Dynamics (5th Ed.). Belmont: CA, Wadsworth, Cengage Learning.

Frohlich, N. (2007). A very short history of distributive justice. Social Justice Research, 20(2), 250-262.

Matthews, G. \& Deary I.J. (1998). Personality traits. Cambridge, UK: Cambridge University Press.

Gelissen, J., \& de Graaf, P. M. (2006). Personality, social background, and occupational career success. Social Science Research, 35(3), 702-726.

Graziano, W. G. (1994). The development of agreeableness as a dimension of personality. In: Halverson C.F. Jr, Kohnstamm G.A., Martin RP (editors). The developing structure of temperament and personality from infancy to adulthood. Hillsdale, NJ: Erlbaum 
Griffin, M. L. (2007). Women as Breadwinners: The Gendered Nature of Side-Bets and Their Influence on Correctional Officers' Commitment to the Organization. Women \& Criminal Justice, 17(1), 1-25.

Hettema, J. M., Neale, M. C., Myers, J. M., Prescott, C. A., \&Kendler, K. S. (2006). A population-based twin study of the relationship between neuroticism and internalizing disorders. American journal of Psychiatry, 163, 857-864.

Hough, L. M., Eaton, N. K., Dunnette, M. D., Kamp, J. D., \& McCloy, R. A. (1990). Criterion-related validities of personality constructs and the effect of response distortion on those validities. Journal of applied psychology, 75(5), 581.

John, O.P. \& Srivastava, S. (1999). The Big Five trait taxonomy: History, measurement, and theoretical perspectives. In Pervin, L.A. and John, O.P. (editors). Handbook of personality: Theory and research.2nd ed. New York: Guilford Press

Kenney, J. F. \& Keeping, E. S. (1962) Linear Regression and Correlation,Ch. 15 in Mathematics of Statistics, Pt. 1, 3rd ed. Princeton, NJ: Van Nostrand

Kohnstamm, G. A., Halverson Jr, C. F., Mervielde, I., \&Havill, V. L. (1998). Analyzing parental free descriptions of child personality. Parental descriptions of child personality: Developmental antecedents of the Big Five, 1-19.

Lim, B. C., \&Ployhart, R. E. (2004). Transformational leadership: relations to the fivefactor model and team performance in typical and maximum contexts. Journal of Applied Psychology, 89(4), 610.

Malouff, J., Bauer, M., Mantelli, D., Pierce, B., Cordova, G., Reed, E., \&Schutte, N. (1990). Development and evaluation of a measure of the tendency to be goal oriented. Personality and Individual Differences, 11(12), 1191-1200.

Meyer, J. \& Allen, N. (1997). Commitment in the Workplace: Theory, Research and Application, Thousand Oaks, CA: Sage.

Mount, M. K., \& Barrick, M. R. (1998). Five reasons why the "Big Five" article has been frequently cited. Personnel psychology, 51(4), 849-857.

Mount, M. K., Barrick, M. R., \& Stewart, G. L. (1998). Five-factor model of personality and performance in jobs involving interpersonal interactions. Human performance, 11(2-3), 145-165.

Mowday, R., Porter, L., \& Steers, R. (1982). Employee-Organization Linkages: The Psychology of Commitment, Absenteeism, and Turnover. New York: Academic Press.

Reynaud, E., El Khoury-Malhame, M., Rossier, J., Blin, O., \&Khalfa, S. (2012). Neuroticism modifies psychophysiological responses to fearful films. PloS one, 7(3), e32413.

Rubin, D. C., Berntsen, D., \&Bohni, M. K. (2008). A memory-based model of posttraumatic stress disorder: evaluating basic assumptions underlying the PTSD diagnosis. Psychological review, 115(4), 985.

Norris, C. J., Larsen, J. T., \&Cacioppo, J. T. (2007). Neuroticism is associated with larger and more prolonged electrodermal responses to emotionally evocative pictures. Psychophysiology, 44(5), 823-826.

Mueller, C. W., \& Price, J. L. (1989). Some consequences of turnover: A work unit analysis. Human Relations, 42(5), 389-402. 
Pulkkinen, L., Männikkö, K., \&Nurmi, J. E. (2000). Self-description and personality styles. Developmental science and the holistic approach, 265-280.

Rothmann, S., \&Coetzer, E. P. (2003). The big five personality dimensions and job performance. SA Journal of Industrial Psychology, 29(1).

Schmutte, P. S., \&Ryff, C. D. (1997). Personality and well-being: reexamining methods and meanings. Journal of Personality and Social Psychology, 73(3), 549.

Strack, S. (Ed.). (2006). Differentiating normal and abnormal personality. Springer Publishing Company.

Thompson, E. R. (2008). Development and validation of an international English big-five mini-markers. Personality and Individual Differences, 45(6), 542-548.

Waldman, D. A., Atwater, L. E., \& Davidson, R. A. (2004). The role of individualism and the five-factor model in the prediction of performance in a leaderless group discussion. Journal of personality, 72(1), 1-28. 